who worked with him. He is survived by his wife Esther and daughters Hilary and Elissa, to whom we all extend our sympathy

F.R.H.W.

(For the members of the Department of Anaesthesia, Wellesley Hospital)

\section{Doctor Alun Philip Thomas}

Friends and colleagues moum the death October 27, 1982 of Dr. Alun Philip Thomas, a dedicated practitioner of the art and science of anaesthesiology.

Born in 1926 in Aberdare, County Glamorgan, Wales, Alun achieved a BSC at the University of Wales in 1947, and graduated from the Welsh National School of Medicine (MB, BCH) in 1950. Alun completed his post-graduate education in anaesthesia, mainly in Liverpool, and spent two years in the Royal Air Force. Alun and Jean Thomas brought their family to Kamloops where he began practice with the Irving Clinic. For several years Alun did some general practice and endeared himself to his patients for his caring and willing ways. Dr. Thomas was the first fully qualified anaesthetist in Kamloops and perhaps in the interior of British Columbia. He established the high standard of service which remains today, and more than one surgeon established a practice in Kamloops because of this assurance. His enthusiastic support and participation contributed both to the establishment of the Intensive Care Unit in 1965, and to its subsequent success. Related to this was his role in establishing the first cardiopulmonary resuscitation program in the Royal Inland Hospital, and the ongoing program of teaching CPR to both medical staff and hospital employees. Whatever Alun did, he did with ardour and tenacity, whether it was his voracious appetite for reading, his commitment to hockey, or his commitment to his profession. Whenever a colleague abandoned hope of winning an argument with Alun, whether it was with a sense of frustration or inadequacy, the later recounting always concluded, "but he is a damned fine anaesthetist," to which I would add, "and a damned fine man."

Left to mourn Dr. Alun P. Thomas are his wife Jean, daughters Christine, Gillian and Rebecca, his sons David and Robert, and of course, his many friends and colleagues who have loved and respected him these many years. Alun was one of those who left his indelible mark on the community, but in ways that not all can see.

\section{G.R.D.}

Kamloops 